УДК 338. 48

\title{
ПІДВИЩЕННЯ ЕФЕКТИВНОСТІ ВІРУСНОГО МАРКЕТИНГУ ЗА ДОПОМОГОЮ ВІЗУАЛЬНОГО КОНТЕНТУ
}

\author{
Зибіна К.В., асистент, \\ Сиволовський I.М., студент (ХНУРЕ)
}

Узагальнено вітчизняний $i$ закордонний досвід використання заходів контентмаркетингу, та його креативного різновиду - вірусного маркетингу. Систематизовано найбільш ефективні інструменти контент-маркетингу $i$ визначено його основні напрямки застосування в практичній діяльності сучасного украйнського бізнесу. Розглянуто недоліки і переваги вірусного маркетингу, зокрема bиzz- маркетингу, приклади доцільного та невдалого застосування. Визначено, щзо за допомогою вірусного маркетингу рекламна інформація розповсюджсуться у вигляді «сарафанного радіо», в геометричній прогресії, а носіями інформачії є самі отримувачі рекламного звернення. Наведено основні складові вірусного контенту, надано їх характеристику та схему технологію розповсюдження маркетингової інформації.

3 врахуванням закордонного досвіду визначено специифіку та високу ефективність застосування вірусного маркетингу, завдяки швидкий ланцюговій реакиії розповсюдження рекламного звернення серед потенційних споживачів. Обтрунтовано необхідність впровадження візуального контенту в ьиzz - маркетинг, як високоефективного заходу маркетингових комунікацій.

Ключові слова: вірусний маркетинг, ьиzz-маркетинг, маркетинг чуток, контент- маркетинг, маркетингові комунікації, візуальній контент, цільова аудиторія, ефективність реклами, медіа простір.

\section{ПОВЫШЕНИЕ ЭФФЕКТИВНОСТИ ВИРУСНОГО МАРКЕТИНГА ПРИ ПОМОЩИ ВИЗУАЛЬНОГО КОНТЕНТА}

\author{
Зыбина К.В., асистент, \\ Сиволовский И.М., студент (ХНУРЭ)
}

Проведен анализ отечественного и зарубежного опыта использования средств контент-маркетинга, и его креативной разновидности - вирусного маркетинга. Систематизированы наиболее эффективные инструменты контент-маркетинга и определень его основные направления применения в практической деятельности современного украинского бизнеса. Рассмотрень недостатки и преимущества вирусного маркетинга, в частности ьиzz- маркетинга. Определено, что с помощью вирусного маркетинга рекламная информачия распространяется в виде «сарафанного радио», а носителями являются сами получатели рекламного обращения. Рассмотрень основные составляющие вирусного контента, представлена их характеристика и схема - технология распространения информации. Определена специифика и эффективность применения вирусного маркетинга, благодаря быстрой иелной реакции распространения рекламного обращения. Обоснована необходимость внедрения визуального контента в bиzz - маркетинг, как высокоэффективного средства маркетинговых коммуникаичй.

(C) Зибіна К.В.,

Сиволовський I.M.

Вісник економіки транспорту і промисловості № 63, 2018 
Ключевые слова: вирусный маркетинг, ьиzz-маркетинг, маркетинг слухов, контент - маркетин, маркетинговые коммуникации, визуальный контент, целевая аудитория, эффективность рекламы, медиа пространство.

\title{
IMPROVING THE EFFICIENCY OF VIRAL MARKETING WITH VISUAL CONTENT
}

\author{
Zybina K., assistant, \\ Sivolovsky I.M., student (KNURE)
}

An analysis of domestic and foreign experience of the use of content-marketing tools, and its creative nature - viral marketing has been analyzed. The most effective tools of content marketing are systematized and its main directions of application in the practical activity of modern Ukrainian business are determined. The disadvantages and advantages of viral marketing, in particular buzz marketing, are considered. It has been determined that with the help of viral marketing, advertising information is distributed in the form of "Sarafan Radio», and the recipients of the advertising appeal themselves are the carriers. The main components of the virus content are presented, their characteristics and the scheme are given - technology of information dissemination. The specificity and effectiveness of the application of viral marketing has been determined, thanks to the rapid chain reaction of the distribution of advertising appeal. The necessity of introducing visual content into buzz marketing as a highefficiency means of marketing communications is substantiated.

Key words: viral marketing, buzz marketing, word-of-mouth marketing, content marketing, marketing communications, visual content, target audience, advertising effectiveness, media space.

Постановка проблеми. Сучасний український медіа-простір не відстає від світових трендів на застосування нових креативних заходів маркетингових комунікацій. Одним $з$ таких $€$ контентмаркетинг, який успішно використовується як великими кампаніями, так підприємства середнього та малого бізнесу. Широке використання прийомів контент-маркетингу виявило його суттєвий недолік, а саме - агресивна подача рекламної інформації в Інтернеті. Цілком природно, що споживачі таку інформацію ігнорують, бо вважають, що на них тиснуть, їм нав'язують товари чи послуги, а деяким здається, що їх обманюють.

Як альтернатива прямому контентмаркетингу, для формування лояльності 3 боку споживачів, з'явився вірусний маркетинг. Сутність цього інструменту маркетингової комунікації полягає у непрямому просуванні, ненав'язливій презентації товару, послуги чи бренду. Тема ефективного використання вірусного маркетингу для українського бізнесу $\epsilon$ новою, а значить актуальною і необхідною для проведення дослідження.

Аналіз останніх досліджень i публікацій. Дослідження і наукові засади використання вірусного маркетингу, як перспективного напрямку контентмаркетингу, здійснювали у своїх працях: Долинська Р.Г., Піткевич К. О. [9], Тринчук В. О., Короленко В. Н. [2], Новаківський I. I., Самохотіна К. Т. [4], Немченко А. О., Раца О. Б. [5], Черняєва К. [8]. Зростання кількості наукових публікацій за вказаною тематикою свідчить про затребуваність методичного і практичного інструментарію 3 використанням технологій вірусного маркетингу.

Виділення невирішених частин загальної проблеми. Усі існуючи дослідженні і рекомендації з підвищення 
ефективності контент-маркетингу i вірусної реклами, одначе, не стосуються застосування візуального контенту при проведенні рекламних кампаній в Internet. Це свідчить про актуальність теми, а відтак, зумовило вибір напряму дослідження.

Мета статті полягає в узагальнені досвіду застосування інструментів та заходів вірусного маркетингу та доведено необхідність впровадження віртуального контенту в Buzz-маркетинг.

Виклад основного матеріалу. В сучасному світі малоефективної реклами, потенційного споживача можна залучити тільки шляхом надання актуальної для нього та цінної інформації, тобто прорекламувати йому те, що він насправді шукає, чим цікавиться. Цю функцію успішно виконує контент-маркетинг через соціальні мережі, веб-сайти, мобільні додатки та інші. Аналіз досвіду застосування різних інструментів контентмаркетингу в діяльності міжнародних та вітчизняних компаній дозволив провести систематизацію цих заходів. До найбільш ефективних видів контент-маркетингу належать:

1. маркетинг чуток (Buzz Marketing): рекламне повідомлення поширюється через обмін думками про товар (бренд) між покупцями i їхніми друзями, сусідами, членами сім'ї, колегами. $\mathrm{У}$ якості каналів розповсюдження виступають розважальні та новинні ресурси, де люди можуть віртуально спілкуватись;

2. вірусний маркетинг (Viral Marketing): створення розважальних або інформативних повідомлень, розроблених 3 метою поширення в геометричній прогресії між потенційними споживачами, часто в електронному вигляді;

3. маркетинг співтовариств (Community Marketing): створення, підтримка i забезпечення спільнот, об'єднаних спільним інтересом до товарів (брендів), контентом і необхідною їм інформацією. Це можуть бути: групи користувачів, фан-клуби, дискусійні форуми;

4. народний маркетинг

(Grassroots Marketing): збір і мотивація добровольців для поширення інформації в персональному (коло друзів) або місцевому масштабі;

5. маркетинг прихильників (Evangelist Marketing): залучення i мотивація пропагандистів, прихильників i добровольців і заохочення їх до активного поширення інформації від вашого імені;

6. «вкинення» товару розміщення цікавого для цільової аудиторії товару (часто новинки) в потрібному місці в потрібний час, постачання інформації про товар, його виробника, фото/відео авторитетних людей (так званих, «лідерів думок»), які $\epsilon$ споживачами цього товару;

7. маркетинг впливу (Influencer Marketing): визначення основних угрупувань і лідерів думок, в перспективі готових обговорювати товари (бренди) фірми-виробника i здатних при цьому впливати на думки інших людей;

8. ситуаційний маркетинг (Cause Marketing): робота 3 соціально значущими проблемами 3 метою завоювання поваги і підтримки людей, що приймають такі проблеми близько до серця; часто використовується при політичній рекламі;

9. створення теми: цікава або кумедна реклама, повідомлення електронної пошти, фрази-виверти, розваги або промо-акції, створені з метою запуску «сарафанного радіо»;

10. бренд-блогінг: створення блогів i участь в блогосфері в формі відкритих, прозорих комунікацій; обмін цінною інформацією з учасниками блогу;

11. партнерські програми: створення інструментів, що полегшують задоволеним споживачам товару (бренду, послуги) передачу інформації друзям.

Усі ці інструменти контентмаркетингу $\epsilon$ дуже ефективними, але багатьом людям вони вважаються 
докучливими, «жорсткими»

нав'язливими. Для комунікатора - це ознаки абсолютної не ефектності рекламного звернення. 3 метою усунення недоліків на перші позиції в світових рейтингах інноваційних заходів маркетингових комунікацій вийшов вірусний маркетинг.

За допомогою

маркетингу рекламна інформація розповсюджується «м'яко» на кшталт «сарафанного радіо», «з вуст в уста», в геометричній прогресії, а носіями (каналами) інформації є самі отримувачі звернення. Цей прийом, а саме відсутність класичного каналу комунікації (телебачення, радіо, зовнішньої реклами та інших), формує у потенційного споживача думку, що він просто отримує пораду, консультацію або досвід від іншої людини, а зовсім не рекламу.

Обов'язковою умовою у вірусному маркетингу $\epsilon$ авторитетність джерела інформації («лідер думки»), бо потенційний споживач повинен довіряти розповсюджувачу, інакше він буде сприймати інформацію як «проплачене» рекламне звернення.

Далі процес вірусної комунікацій відбувається за схемою: при позитивному сприйнятті інформації отримувач рекламного звернення миттєво сам стає «рекламодавцем» для інших потенційних споживачів зі свого оточення, буквально «заражаючи» їх. Звісно, хтось 3 «заражених» не сприйме інформацію, або навіть, негативно ii сприйме, тоді цей канал перерветься, але більшість отримувачів все-таки «проковтнуть» інформацію і перетворяться на «носія вірусу». Так процес вірусної маркетингової комунікації продовжиться.

Термін «вірусний маркетинг» був вперше використаний Джефрі Рейпортом, академіком Гарвардської Бізнес-школи у 1996 році. Ця ідея отримала широке розповсюдження разом 3 поширенням Інтернету й електронної торгівлі [1]. Зі зростанням он-лайнових соціальних мереж, таких як YouTube i Facebook, вірусний маркетинг вийшов на якісно новий рівень. В мережах інформація поглинається користувачами набагато швидче і в більшій кількості, ніж при користуванні електронною поштою. Це збільшує i без того великий потенціал вірусного маркетингу. Ефективність вірусної компанії вимірюється як кількісними показниками: кількість відвідувачів, час контакту, кількість посилань, так і якісними: динаміка згадки проекту в засобах масової інформації, розміщення посилань в блогах, соціальнодемографічний склад аудиторії проекту [2].

Результати досліджень компаній Wetpaint i Altimeter Group показують, що компанії і бренди, які найбільш активно здійснюють комунікації в соціальних мережах, за останні роки збільшили свій прибуток на $18 \%$, у той час як у решти представників ринку продажі впали в середньому на 6\% [3]. Сьогодні основними каналами розповсюдження вірусного маркетингу є: соціальні мережі, топ - блоги, товариства (LiveJournal), інформаційні інтернет-портали, форуми, фото/відео хостинги (YouTube). Для ефективного поширення вірусного повідомлення слід дотримуватися таких вимог [4]:

- повідомлення має бути актуальним для визначеної цільової аудиторії;

ідея повідомлення повинна містити, щось нове й цікаве;

- з зв'язок реклами 3 кінцевою метою має бути невідчутним;

- повідомлення повинно легко поширюватись та сприйматись;

необхідне виникнення

«вірусної хвилі», щоб основна кількість переглядів припала на перші 2-3 тижні.

Девізом вірусного маркетингу $\epsilon$ фраза: «Побачив, лайкнув, заразив». Незалежно від каналу вірусна реклама кампанія повинна включати етапи [5]: 
1. ідея (big idea) - те, з чого все починається, і навколо чого «крутиться»;

2. виробництво (production) реалізація ідеї;

3. посів (seeding) - це початкова точка «вкидання» вірусного контенту для його подальшого самостійного розповсюдження.

Крім того, при проведенні вірусної маркетингової кампанії треба відповісти на наступні питання (таблиця 1, перероблена та доповнена за матеріалами $[6])$.

Основні складові вірусного контенту та їх характеристика

Табличя 1

\begin{tabular}{|c|c|}
\hline Складові & Характеристика \\
\hline \multirow[t]{4}{*}{ 1. Цільова аудиторія } & Стать (на кого розрахований контент) \\
\hline & $\begin{array}{l}\text { Вік (молодь у віці від } 15 \text { до } 24 \text { років або більше } \\
\text { дорослі споживачі) }\end{array}$ \\
\hline & $\begin{array}{l}\text { Регіон проживання (Західна Україна, Східна } \\
\text { Україна, українці за кордоном) }\end{array}$ \\
\hline & $\begin{array}{l}\text { Сфера діяльності, соціальний статус або хобі } \\
\text { (програмісти, «мамочки», «модні дівчата», } \\
\text { «любителі японської кухні») }\end{array}$ \\
\hline $\begin{array}{l}\text { 2. Канал розповсюдження } \\
\text { вірусної інформації }\end{array}$ & Instagram, Facebook, YouTube, Twitter, \\
\hline \multirow[t]{2}{*}{$\begin{array}{l}\text { 3. Смаки та уподобання цільової } \\
\text { аудиторії }\end{array}$} & $\begin{array}{l}\text { Характер контенту (розважальний, пізнавальний, } \\
\text { провокаційний, гумористичний) }\end{array}$ \\
\hline & $\begin{array}{l}\text { Формат контенту (відео, інфографіка, зображення, } \\
\text { безкоштовна гра) }\end{array}$ \\
\hline
\end{tabular}

Одначе, всі ці складові вірусної рекламної кампанії, можуть не спрацювати.

Бо в останнім часом потенційні споживачі стають більш вибагливими до сутності і вигляду інформаційного контенту. Досліджено, що кожна велика соціальна мережа, в тому числі Facebook, Twitter, LinkedIn i Instagram, з року в рік збільшують свою популярність за рахунок візуального контенту. Згідно досліджень у 2017 році компанією Social Media Ехамінер [7]:

1. $32 \%$ маркетологів вважають, що візуальні образи $\epsilon$ найважливішою формою контенту для бізнесу, а текстові блоги посідають лише друге місце (27\%);

2. $80 \%$ маркетологів використовують візуальний контент в маркетингу соціальних мереж. Кількість просмотрів відео у 2017 році (63\%) перевищило кількість просмотрів блогів (60\%);
3. коли люди чують інформацію, через три дні вони пам'ятають лише $10 \%$ цієї інформації. Проте, якщо відповідне зображення поєднано 3 тією ж інформацією, через три дні люди пам'ятають біля 65\% інформації;

4. маркетологи, що працюють с товарами споживчого призначення частіше використовують оригінальні відео (63\% проти 56\%) та оригінальні візуальні засоби (63\% проти 56\% ) ніж маркетологи, працюючи на ринку промислових товарів;

5. у 2017 році використання відеоконтенту для промислового маркетингу збільшилося на 8\% до 58\%;

6. 86\% покупців інтернет-магазинів висловили певний рівень бажання отримувати доступ до інтерактивного/візуального контенту за своїм запитом.

На нашу думку до найбільш ефективних засобів візуального контенту відносять. 
1. Фотографії / фото. Картинка може сказати більше, ніж тисяча слів і повідомити читачам багато інформації за кілька секунд. Зображення краще запам'ятовуються, допомагають читачам швидше зрозуміти сутність матеріалу.

2. Інфографіка. Це - один 3 найбільш актуальних видів візуального контенту в даний час. Зростання iі популярності навчило фірми втискати багатосторінкові звіти i результати досліджень у кілька десятків яскравих картинок. Так бренди змушують клієнтів ознайомитися 3 важливими даними i поділитись інформацією 3 друзями в соціальних мережах. Як правило, користувачі діляться інфографікою в соціальних мережах в 3 рази більше, ніж будь-яким іншим контентом. Інфографіка об'єднує багато різної інформації і може містити малюнки, тексти, графіки.

3. Відео. За статистикою більше $60 \%$ читачів, які дивляться відео, купують продукти i послуги, які рекламуються онлайн [7]. Відеоконтент на «відмінно» підтримує бренд i підкреслює його переваги. Півхвилинне відео покаже споживачеві набагато більше, ніж велика стаття.

4. «Мережеві» банери. Одна 3 останніх оригінальних новинок в Instagram - «мережеві» банери, які дозволяють користувачам розділяти велику фотографію на дрібні частини i представляти їх у формі єдиного складеного банера. Такі складові банери або колажі зараз дуже популярний рекламний засіб.

5. Цитати. Будь-який текст або навіть невеликий пост стане більш переконливим, якщо додати в нього цитату. За допомогою картинки можна посилити текст, зробивши акцент на певній його частині. Або розмістивши фото знаменитості, приправлене цитатою. Наприклад, Біла Гейтса 3 його знаменитим висловом: «Будьте доброзичливі до ботаників. Швидше за все, в майбутньому, ви будете працювати на одного з них»
6. Меми. Головна мета сатиричних мемів в інтернеті - зробити контент більш популярним. Хіба це не причина використовувати їх в візуальному контент-маркетингу? Зазвичай меми посилаються на актуальні новини або події і підносять їх в гумористичній формі. Тому їх потрібно акуратно використовувати в якості реклами, щоб вони не стали антирекламою товару.

7. Кнопки iз закликом. «Купити зараз», «Приєднатися», «Опублікувати», «Отримати безкоштовно» - це приклади заклику до певної дії, які можуть бути розміщені на кнопках і відігравати важливу роль в стратегії візуального контент-маркетингу. Такі кнопки часто використовуються маркетологами для отримання миттєвої реакції споживачів. Будь-який користувач може натиснути на них і отримати те, що пропонується. Це майже ідеальна форма швидкого продажу.

Не дивлячись на те, що вірусний маркетинг $\epsilon$ новим, ефективним i перспективним засобом маркетингової комунікації треба також розглянути його недоліки. До них належать його непередбачуваність та нестабільність [8].

Перша ознака вказує на те, що вірусний маркетинг - це суміш вірних ідей i удачi. Запланований маркетологами «вірус», може бути 3 апетитом «з'їдений і проковтнутий» цільовою аудиторією, а може бути виплюнутий. Навіть якщо рекламодавці вважають свою ідею креативною, цікавою, захопливою, це не свідчить про іiі стовідсоткову ефективність. Друга ознака вірусної реклами вказує на мінливість смаків потенційних споживачів i на нестабільність рейтингів популярності інтернет-ресурсів. Наприклад, політичний блогер Олег Пономарь, зазнає то злети, то падіння рейтингу, а це означає, що i товари, які він рекламує, також будуть мати різні обсяги продажів.

Взагалі найбільша кількість прикладів вірусного маркетингу, представлених в україномовних інтернет- 
виданнях, стосується закордонних суб'єктів великого бізнесу. Це цілком закономірно, оскільки діяльність великих компаній найбільш широко висвітлюється в засобах масової інформації. Слід зазначити, що вперше на українському ринку малобюджетні технології маркетингу були офіційно використані великими закордонним компаніями. До числа міжнародних компаній, що використовують малобюджетні технології в комплексі маркетингових комунікацій на українському ринку, належать такі транснаціональні корпорації, як Nokia, Tuborg, Samsung, Boeing, Sony, Nestle, Microsoft, Google, Danone тощо [9]. До українських підприємств, які використовують в своїй діяльності вірусний маркетинг, можна віднести приватних виробників взуття, сумок, одягу, що працюють за індивідуальним замовленням: Kravets hand made, $\mathrm{Mr}$. Brown, Babak, Universal Hedonism, Cardo, Твій стиль с 2010 року та інших.

Висновки. Проведене дослідження методів, прийомів i світового досвіду використання вірусного маркетингу довело, що в реаліях сучасного українського бізнесу вірусний маркетинг при умілому використанні його інструментів $\epsilon$ найдешевшим i найефективнішим заходом маркетингових комунікацій. Його впровадження можливе для рекламування будь-яких споживчих товарів або послуг масового призначення. Маркетологу достатньо просто «вкинути» інформацію в медіа простір, щоб іiі дізнались п'ять - десять споживачів 3 цільової аудиторії, а далі почнеться ланцюгова лавиноподібна реакція. Втручання маркетологів в процес більше не потрібне, вірусна комунікація сама забезпечить собі життя без жодних грошових вкладень в рекламне звернення.

Одначе, методологія процесу розповсюдження вірусного маркетингу показує, що створення вірусної компанії схоже на гру в рулетку - може спрацювати, а може - ні. По-перше, потенційні

споживачі

здатні

проігнорувати «вірусне вкинення», в цьому випадку «лавини» не буде, подруге, маркетологи підприємства не можуть контролювати розповсюдження i розвиток вірусу. А це означає, що крім позитивного сприйняття, i як слідство, високих продажів, вірусна рекламна кампанія може дати протилежний ефект 3 негативними наслідками.

Тому при плануванні комплексу маркетингових комунікацій підприємство повинно використовувати не тільки вірусний маркетинг, а й інші заходи розповсюдження інформації, щоб не втратити контроль над рекламною стратегією.

\section{ПЕРЕЛІК ВИКОРИСТАНИХ ДЖЕРЕЛ}

1. Всеукраїнський портал інноваційних технологій. Режим доступу http://www.innovations.com.ua

2. Тринчук В. О., Короленко В. H. Вірусний маркетинг страхових компаній / В. Тринчук, В. Короленко // Страхова справа. - 2010. №1. - C. 42-47.

3. Що стримує вклади у соцмедіа // MediaRevolution. [Електронний ресурс]: Режим доступу: http://www.mediarevolution.ru/advertiser/ma rkets/2355.html

4. Новаківський I. I. Сучасний вірусний маркетинг в Україні [Електронний ресурс] / I. I. Новаківський, К. Т. Самохотіна // Маркетинг та логістика в системі менеджменту: тези доповідей IX Міжнародної науково-практичної конференції (Львів, 8-10 листопада 2012 p.)/Національний університет «Львівська політехніка». - Львів : Видавництво Львівської політехніки, 2012. - С. 304 306. - Режим доступу http://ena.lp.edu.ua/bitstream/ntb/16901/1/18 7-Novakivsky-304-306.pdf

5. Немченко А. О. Вірусний маркетинг - переваги та недоліки [Електронний ресурс] / А. О. Немченко, О. 
Б. Раца. - Режим доступу: http://nauka.kushnir.mk.ua/?p=38569

6. How to: Что такое вирусный маркетинг и как его делать? [Електронний pecypc]. - Режим доступу https://blog.seopult.ru/seotech/how-to-chtotakoe-virusnyj-marketing-i-kak-egodelat.html

7. 45 Visual Content Marketing Statistics You Should Know in 2018 [Електронний ресурс]. - Режим доступу: https://blog.hubspot.com/marketing/visualcontent-marketing-strategy
8. Карина Черняєва. Вірусний маркетинг: ефективність, особливості та його приклади/ [К. Черняєва] [Електронний ресурс]. - Режим доступу: https://marketer.ua/ua/efektivnist-virusnogomarketingu

9. Долинська Р.Г., Піткевич К. О. Міжнародний досвід використання мало бюджетних технологій у комплексі маркетингових комунікацій / Р.Г. Долинська, К.О. Піткевич // Вісник НТУ «ХПІ». - 2014. - №45. - С. 8-14.

\title{
УДК 330.64:438.658.4
}

\section{ПІДХОДИ ДО ЗАБЕЗПЕЧЕННЯ СТРАТЕГІЧНОГО УПРАВЛІННЯ ПІДПРИЕМСТВА В УМОВАХ НЕСТІЙКОГО СЕРЕДОВИЩА}

\author{
Науменко М.О., д. філ. екон. напр., професор,
} Рига O.C., мazicmp (НАНГУ)

У статті розглянуто особливості функціонування підприємств харчової промисловості та доведено необхідність перегляду конщептуальних основ стратегічного управління. Проаналізовано існуючі на разі теоретичні положення стратегічного управління підприємством. Визначено, щчо сучасне управління трудовими ресурсами не можливе без інноваційної діяльності, а саме інноваційного кадрового менеджменту. Розкрито основні функиії інноваційного кадрового менеджменту для підприємств сфери послуг. Удосконалено методичні положення стратегічного управління підприємством харчування за рахунок перегляду матрииі стратегічного вибору, щзо враховує ймовірність негативних подій та інтенсивність їх впливу.

Ключові слова: стратегічне управління, управлінська діяльність, підприємство, адаптація, нестабільність.

\section{ПОДХОДЫ К ОБЕСПЕЧЕНИЮ СТРАТЕГИЧЕСКОГО УПРАВЛЕНИЯ ПРЕДПРИЯТИЯ В УСЛОВИЯХ НЕУСТОЙЧИВОЙ СРЕДЫ}

\author{
Науменко М.А., д. фил. экон.напр., профессор, \\ Рига А.С., магистр (НАНГУ)
}

В статье рассмотрены особенности функционирования предприятий пищевой промышленности и доказана необходимость пересмотра концептуальных основ

(C) Науменко M.O.,

Рига O.C.
Вісник економіки транспорту і промисловості № 63, 2018 